\title{
The Effect of Debate Technique towards Eleventh Grade Students' Speaking Competency
}

\author{
Putu Shela Widiawati ${ }^{*}$, Ni Made Ratminingsih², Dewa Ayu Eka Agustini ${ }^{3}$
}

1,2,3 Ganesha University of Education

A R T I C L E I N F O

Article history:

Received 07 February

2020

Received in revised

Form 14 March 2020

Accepted 20 April 2020

Available online 30

August 2020

Keywords:

ELT, speaking, debate

\section{A B S T R A C T}

Among the four pivotal skills, speaking signifies part of the most essential skill because its role primarily serves as a means of communication. Speaking is an interactive process of developing, creating, constructing and delivering meaning with goal of information exchanges between speaker and hearer. some students still faced some problems to communicate in English. Many students did not show their readiness in speaking English spontaneously. This study aimed at investigating the significant effect of debate technique on students' speaking competency, this quasi-experimental research employed 70 student participants from two social science classes, who were randomly assigned to the experimental condition and to the control condition. The instruments used for collecting the data were performance of speaking test and rubric for students' speaking assessment. The data were analysed by using descriptive and inferential analyses. The result of this study shows that the mean score of experimental group is 79.79, while the mean score of control group is 75.25 . The result of $t$ test shows that the value of Sig. (2-tailed) is .000 , which indicates a significant mean different. Therefore, this study concludes that debate technique affects students' speaking competency. In addition to it, the contribution to the teaching of speaking as well as implications for future research are also discussed.

\section{Introduction}

Among the four pivotal skills, speaking signifies part of the most essential skill because its role primarily serves as a means of communication. Speaking is an interactive process of developing, creating, constructing and delivering meaning with goal of less competent to speak English (Derakhshan, Khalili, \& Beheshti, 2016; Khan, Radzuan, Shahbaz, Ibrahim, \& Mustafa, 2018; Ratminingsih, 2017). Apart from the internal aspects of students, the external aspects which include the strategies used by the teacher also greatly affect the learning process of speaking skills (Abda, 2017; Mahmoudi \& Mahmoudi, 2015).

In the practice of teaching and learning speaking skill, the role of the teacher is very important. Teachers in this decade are expected to be able to apply the $21^{\text {st }}$ century skill values that include communication, collaboration, critical thinking and problem solving, and creativity and innovation (Handayani, 2017; Yu, Muna, \& Wan, 2019). One of the teaching techniques for speaking skill that reflects the $21^{\text {st }}$ century abilities is debate. Debate is a systematic structured and regulated discussion of specific issues that evoke differences of opinion, create confrontation of two different point of views (Al-Mahrooqi \& Tabakow, 2015). Through a debate, two sets of perspectives/values/policies are established, one arguing in support of the motion and the other opposing it (Alasmari \& Ahmed, 2013; Cinganotto, 2019). A debate in a foreign language can be used as a reflection of communicative approach to develop a wide range of communicative functions relevant for reaching agreement in a team, connecting phrases and sentences through logical connectors, supporting a point of view with evidence, expressing agreement or disagreeing, or showing interest and appreciation of a speech (Alasmari \& Ahmed, 2013; Dalton-puffer, 2013)

There are a number of reasons for using debate in teaching speaking. The use of debate in learning in addition to honing the ability to speak in authentic contexts can also help the students in developing 
their critical thinking and problem solving skills (Alasmari \& Ahmed, 2013; Mumtaz \& Latif, 2017). Debate can be functioned as a teaching-learning strategy generating myriads of enthusiasms among students and assisting them in enhancing their communication skill (Ramlan, Kassim, Pakirisamy, \& Selvakumar, 2016). In addition, many studies have found that debate has a positive effect on students' English speaking ability (Arung \& Jumardin, 2016; Zare \& Othman, 2013; Želježič, 2017). Therefore, it can be stated that there are numerous benefits of using debate in teaching English, especially teaching speaking skill.

Grounded on the observation carried out by the researcher at grade XI of SMA Saraswati Seririt, including interviewing the teacher, the conventional teaching technique such as drilling and repetition were used by the teacher for teaching speaking. The findings show that some students still faced some problems to communicate in English. Many students did not show their readiness in speaking English spontaneously. Besides that, the students seemed reluctant to speak because they were afraid of making grammatical mistakes. From the results of the preliminary observation, it can be said the strategies that have been implemented by the teacher to teach speaking were not yet able to hone his/her students' speaking proficiency. In addition, the strategies used by teacher is not compatible with the $21^{\text {st }}$ century learning where critical thinking and problem-solving skills need to be integrated in teaching and learning process. Therefore, this study aims to determine the effect of debate on students' ability to speak English.

\section{Methods}

The current study is a quasi-experimental with post-test only control group design. It was utilized when two classes were taken randomly as experimental and control groups, which might have the same characteristics (Cresswell, 2012). The design of the current study is post-test only control group design. The groups were treated with different treatment in which the control group was taught with conventional technique, while the experimental was taught with a debate technique.

The population of the study comprised a total number of 70 eleventh-graders of SMA Saraswati Seririt. In this research, the technique utilized to attain the sample was random sampling technique in which it signifies a sampling technique giving an equal chance for all population to be selected as a sample. The sampling was applied through a lottery technique. From the lottery, XI IPS 2 served as the experimental group comprising 34 students. Meanwhile, XI IPS 4 served as the control group comprising 36 students.

There were two instruments used in this study, namely speaking test and rubric for assessing speaking. After conducting the treatment, the students were asked to perform a speaking task. The rubric consists of dimension in guiding to score the students' performance.

In analysing the data, this study employs descriptive and inferential analyses. All data analyses are conducted automatically with SPSS program.

\section{Result and Discussion}

After collecting the data, the next step conducted was analysing the data. The result of the data analysis is presented in table 1 below.

Table 1. The Result of Data Analysis

\begin{tabular}{ccc}
\hline Analysis & \multicolumn{3}{c}{ Result } \\
\cline { 2 - 3 } & Experiment & Control \\
\hline Mean & 79.79 & 75.25 \\
Standard Deviation & 3.804 & 3.383 \\
Normality & .093 (Normal) & .200 (Normal) \\
Homogeneity & \multicolumn{2}{c}{.466 (Homogeneous) } \\
t test (Sig. 2-tailed) & \multicolumn{2}{c}{.000} \\
\hline
\end{tabular}

From the result of data analysis, it can be seen that the mean score of experimental group is 79.79, while the control group is 75.250. This indicates that the mean score of control group is lower than experimental group $(75.25<79.79)$. Before identifying the mean significant between experiment and control group using t-test, a normality and homogeneity test were conducted. The result of normality shows that the data are normally distributed ( $p>05)$ and the result of homogeneity tests shows that the data are homogeneous $(p=>.05)$. Thus, the $t$ test can be conducted.

A significant mean difference is indicated if the value of Sig. (2-tailed) in t-test is lower than 05 . From table 1 , it can be seen that the value of Sig. (2-tailed) is .000 which is lower than .05 . This indicates 
that there is a significant mean difference between experiment and control groups. The result of the current study was similar with a study conducted by Lestari (2018) who found that students' speaking performance was improved after debate technique was implemented. Tianame, Usman, and Muslem (2019) also identified a significant improvement on students' speaking skill after using debate technique in teaching and learning process.

Implementing debate technique in the learning process has altered students, and it gave valuable impacts. For instance, students who belong to the experiment group show higher score in grammar and vocabulary. This is in line with previous studies that found improvement on language aspects after learning by utilizing debate technique (Iman, 2017; Zahra, 2019). Besides that, students were encouraged to participate in the class since the debate was carried out by the students. They were seemingly enthusiastic in the discussion session, were triggered to win the debate, and were active in their groups. Debate can enhance students' involvement in the learning process and appreciate differences and tolerance for others' viewpoints (Brown, 2015; Pradana, 2017). The present study also found that the students' involvement in the class improved as they became more excited and enjoyed teamwork activities. Malone and Michael (2018) mention that besides learning to enhance critical and problemsolving skill, using debate can also enhance collaborative skill.

Based on the results of this study, the use of debate technique significantly affects students speaking competency. The students in experiment group who were taught with debate technique showed better speaking competency than those in control group. Debate technique can be used by teacher to engage the students in practicing speaking skills. Besides learning to speak English, the use of debates will also hone students critical thinking skill which is necessary in the $21^{\text {st }}$ era. Thus, use of debate is highly recommended in the teaching and learning process of English, especially to practice speaking skills.

\section{Conclusion}

To sum up, students who were taught by utilizing debate technique attained an improvement of speaking score than those who were taught by using conventional technique. There is a significant mean difference in speaking competency among students who were assigned in both control and experimental groups. By comparing the dissimilar average scores in both groups, the researcher concluded that debate technique gave beneficial contributions to students' speaking skill than that of the conventional technique. It implies that debate technique can be effective for teaching speaking.

\section{References}

Abda, K. (2017). Assessing the Factors That Affect Teaching Speaking Skills: The Case of Robe Teachers' College, English Department Second Year Students. International Journal of Humanities \& Social Science Studies, 3(5), 285-299. https://www.academia.edu/download/61222401/1115149147987520191114-82879-sb9g2z.pdf.

Al-Mahrooqi, R. I., \& Tabakow, M. L. (2015). Effectiveness of Debate in ESL / EFL-Context Courses in the Arabian Gulf : A Comparison of Two Recent Student-Centered. 21st Century Academic Forum C, 5(1), 417-428. http://www.academia.edu/download/59824411/Proc_2015_Harvard20190621-16738b2yz9m.pdf\#page=412.

Alasmari, A., \& Ahmed, S. S. (2013). Using Debate in EFL Classes. English Language Teaching, 6(1), 147152. https://doi.org/10.5539/elt.v6n1p147

Arung, F., \& Jumardin. (2016). Improving the Students ' Speaking Skill through Debate Technique. Journal of English Education, 1(1), 70-76. https://doi.org/10.31327/jee.v1i1.85

Bouzar, S. (2019). Issues in Teaching Speaking to EFL Learners. Education and Linguistics Research, 5(1), 70-79. https://doi.org/10.5296/elr.v5i1.14705

Brown, D. (2004). Language Assessment: Principles and Classroom Practices. San Francisco: San Fransisco State University.

Brown, Z. (2015). The use of in-class debates as a teaching strategy in increasing students ' critical thinking and collaborative learning skills in higher education . Educationalfutures, 7(1), 39-55. http://hdl.handle.net/2436/621883

Cinganotto, L. (2019). Debate as a Teaching Strategy for Language Learning. Lingue Linguaggi, 30, 107125. https://doi.org/10.1285/i22390359v30p107 
Cresswell, J. W. (2012). Educational Research. Boston: Pearson.

Dalton-puffer, C. (2013). A construct of cognitive discourse functions for conceptualising contentlanguage integration in CLIL and multilingual education. "European Journal of Applied Linguistics, 1(2), 216-253. https://doi.org/10.1515/eujal-2013-0011

Derakhshan, A., Khalili, A. N., \& Beheshti, F. (2016). Developing EFL Learner' s Speaking Ability , Accuracy and Fluency. English Language and Literature Studies, 6(2), 177-186. https://doi.org/10.5539/ells.v6n2p177

Fauzan, U. (2014). The Use of Improvisations Technique to Improve the Speaking Ability of EFL Students Umar Fauzan. Dinamika Ilmu, 14(2), 265-288. https://doi.org/10.21093/di.v14i2.17

Fauzan, U. (2016). Enhancing Speaking Ability of EFL Students through Debate and Peer Assessment. EFL Journal, 1(1), 49-57. http://dx.doi.org/10.21462/eflj.v1i1.8

Handayani, N. (2017). Becoming the Effective English Teachers in the 21st Century: What Should Know and What Should Do? In 1st English Language and Literature International Conference (ELLiC) (pp. 156-164). https://jurnal.unimus.ac.id/index.php/ELLIC/article/view/2463

Iman, J. N. (2017). Debate Instruction in EFL Classroom: Impacts on the Critical Thinking and Speaking Skill. International Journal of Instruction, 10(4), 87-108. https://eric.ed.gov/?id=EJ1155603

Khan, R. M. I., Radzuan, N. R. M., Shahbaz, M., Ibrahim, A. H., \& Mustafa, G. (2018). The Role of Vocabulary Knowledge in Speaking Development of Saudi EFL Learners. Arab World English Journal, 9(1), 406418. https://doi.org/10.24093/awej/vol9no1.28

Leong, L., \& Ahmadi, S. M. (2017). An Analysis of Factors Influencing Learners ' English Speaking Skill. International Journal of Research in English Education, 2, 34-41. https://doi.org/10.18869/acadpub.ijree.2.1.34

Lestari, F. L. (2018). Debate Technique as Teacher's Strategies in Improving Student's Higher Education English Speaking Skill. Journal of Education of English as Foreign Language, 1(2), 1-9. https://doi.org/10.21776/ub.Educafl.2018.001.02.02

Mahmoudi, S., \& Mahmoudi, A. (2015). Internal and External Factors Affecting Learning English as a Foreign. International Journal of Language and Linguistics, 3(5), 313-322. https://doi.org/10.11648/j.ijll.20150305.16

Malone, Y., \& Michael, T. (2018). Collaborative learning and critical thinking skills : Effects. International Journal of Learning and Teaching, 10(1), 61-69. https://doi.org/10.18844/ijlt.v10i1.3146

Mumtaz, S., \& Latif, R. (2017). Learning through debate during problem-based learning : an active learning strategy. Adv Physiol Educ, 41, 390-394. https://doi.org/10.1152/advan.00157.2016

Pradana, S. A. (2017). Using Debate to Enhance Students' Speaking Ability as their Character Building. English Education: Jurnal Tadris Bahasa Inggris, 10(1), 149-163. https://doi.org/10.24042/eejtbi.v10i1.881

Ramlan, F. A., Kassim, N. M., Pakirisamy, S., \& Selvakumar, V. (2016). The Impact of Debates as a Teaching Strategy in the Classroom to Medical Students. Academia Journal, 5(2), 194-203. http://103.8.145.246/index.php/JeA/article/view/1445

Rao, P. S. (2019). The importance of speaking skills in english classrooms. Alford Council of International $\begin{array}{llll}\text { English \& Literature 6-18. } & \text { Journal, }\end{array}$ https://www.researchgate.net/profile/Parupalli_Rao/publication/334283040_THE_IMPORTANCE _OF_SPEAKING_SKILLS_IN_ENGLISH_CLASSROOMS/links/5d21b2db458515c11c18dbf3/THEIMPORTANCE-OF-SPEAKING-SKILLS-IN-ENGLISH-CLASSROOMS.pdf

Ratminingsih, N. M. (2017). The Effect of Teaching Techniques and Types of Personality on English Listening Skill. Jurnal Parameter, 29(1), 61-73. https://doi.org/10.21009/parameter.291.07

Shen, M., \& Chiu, T. (2019). EFL Learners ' English Speaking Difficulties and Strategy Use. Education and Linguistics Research, 5(2), 88-102. https://doi.org/10.5296/elr.v5i2.15333

Tianame, M., Usman, B., \& Muslem, A. (2019). The Implementation of Debate Technique to Enhance Students' Speaking Skill. English Education Journal, 10(2), 180-195. http://www.jurnal.unsyiah.ac.id/EEJ/article/view/11923 
Yu, T. X., Muna, W., \& Wan, R. (2019). Integration of 21st Century Learning Skills ( 4C Elements ) in Interventions to Improve English Writing Skill Among 3K Class Students. International Journal of Contemporary Education, 2(2), 100-121. https://doi.org/10.11114/ijce.v2i2.4498

Zahra, I. A. (2019). The Effect of Debate Activity in English Four Skills: The Students' Perspective. In UHAMKA International Conference on ELT and CALL (pp. 57-67). Jakarta: UHAMKA.

Zare, P., \& Othman, M. (2013). Classroom Debate as a Systematic Teaching / Learning Approach. World $\begin{array}{llll}\text { Applied Sciences } 28, & \text { Journal 15), }\end{array}$ https://doi.org/10.5829/idosi.wasj.2013.28.11.1809

Želježič, M. (2017). Debate in the EFL Classroom. English Language Overseas Perspectives and Enquiries, 14(1), 39-54. https://doi.org/10.4312/elope.14.1.39-54 